\title{
Radiographic assessment of the proximal tibial angles in dogs and cats with and without cranial cruciate ligament rupture ${ }^{1}$
}

\author{
Ana Flávia D.P. Arruda², Leonardo A.L. Muzzi ${ }^{3 *}$, Antonio C.C. Lacreta Junior ${ }^{4}$, \\ Ruthnéa A.L. Muzzi ${ }^{5}$, Gabriela R. Sampaio ${ }^{3}$, Stella H. Moreira ${ }^{6}$ \\ and Luciane R. Mesquita ${ }^{7}$
}

\begin{abstract}
Arruda A.F.D.P., Muzzi L.A.L., Lacreta Junior A.C.C., Muzzi R.A.L., Sampaio G.R., Moreira S.H. \& Mesquita L.R. 2018. Radiographic assessment of the proximal tibial angles in dogs and cats with and without cranial cruciate ligament rupture. Pesquisa Veterinária Brasileira 38(6):1190-1195. Departamento de Medicina Veterinária, Universidade Federal de Lavras, Av. Doutor Sylvio Menicucci 1001, Cx. Postal 3037, Kennedy, Lavras, MG 37200-000, Brazil. E-mail: lalmuzzi@dmv.ufla.br

The influence of the proximal tibial angles in the cranial cruciate ligament (CCL) rupture in dogs is still controversial, and little is known regarding this topic in cats. The aim of this study was to evaluate and compare the angles of the proximal portion of the tibia in dogs and cats with and without CCL rupture. Retrospective and prospective radiographs of the stifle joints were obtained and divided into four groups. Group 1 was composed of 70 stifle joint images of dogs without orthopedic disorders (healthy dogs), group 2 had 70 stifle joint images of dogs with CCL rupture, group 3 had 50 stifle joint images of cats without orthopedic disorders (healthy cats) and group 4 had 25 stifle joint images of cats with CCL rupture. Radiographs were taken with the stifle joint in the mediolateral projection, positioned at the angle of hind limb support. Between the two groups of dogs evaluated, the dogs with CCL rupture had statistically greater tibial plateau angle (TPA) compared with healthy dogs. No difference was shown in relation to the TPA between healthy cats and cats with CCL rupture. In relation to the patellar ligament angle by tibial plateau method the values for the healthy dogs were significantly higher than those for the CCL ruptured dogs. Similarly, healthy cats had significantly higher mean values than cats with CCL rupture. In the patellar ligament angle by common tangent method there was no significantly difference between the two groups of dogs. Between the two groups of cats, animals with CCL rupture had statistically higher mean values than healthy cats. In general, the groups of dogs showed higher mean values than the groups of cats. For the patellar ligament insertion angle (PLIA) healthy dogs showed a significantly higher mean than dogs with CCL rupture. There was no significant difference between the groups of cats. In conclusion, the TPA and the PLIA possibly influence the etiology of CCL rupture in dogs but not in cats. The low patellar ligament angle measured by common tangent method may favorably influence the reduced incidence of CCL rupture in cats.
\end{abstract}

INDEX TERMS: Tibial plateau, patellar ligament, stifle joint, dogs, cats, surgery.

\footnotetext{
${ }^{1}$ Received on April 20, 2016.

Accepted for publication on December 22, 2016.

${ }^{2}$ Pós-Graduação em Ciências Veterinárias, Departamento de Medicina Veterinária, Universidade Federal de Lavras (UFLA), Av. Doutor Sylvio Menicucci 1001, Cx. Postal 3037, Kennedy, Lavras, MG 37200-000, Brazil.

${ }^{3}$ Setor de Cirurgia Veterinária, Departamento de Medicina Veterinária, Universidade Federal de Lavras (UFLA), Av. Doutor Sylvio Menicucci 1001, Cx. Postal 3037, Kennedy, Lavras, MG 37200-000. *Corresponding author: lalmuzzi@dmv.ufla.br

${ }^{4}$ Setor de Diagnóstico por Imagem, Departamento de Medicina Veterinária, Universidade Federal de Lavras (UFLA), Av. Doutor Sylvio Menicucci 1001, Cx. Postal 3037, Kennedy, Lavras, MG 37200-000.
}

\footnotetext{
${ }^{5}$ Setor de Clínica Médica de Pequenos Animais, Departamento de Medicina Veterinária, Universidade Federal de Lavras (UFLA), Av. Doutor Sylvio Menicucci 1001, Cx. Postal 3037, Kennedy, Lavras, MG 37200-000.

${ }^{6}$ Residência em Clínica Cirúrgica em Animais de Companhia, Escola de Veterinária, Universidade Federal de Minas Gerais (UFMG), Av. Pres. Antônio Carlos 6627, Pampulha, Belo Horizonte, MG 31270-901, Brazil.

${ }^{7}$ Pós-Graduação em Medicina Veterinária, Universidade Estadual Paulista Júlio de Mesquita Filho, Universidade Estadual Paulista (Unesp), Distrito de Rubião Junior, Botucatu, SP 18618-970, Brazil.
} 
RESUMO.- [Avaliação radiográfica dos ângulos da tibia proximal em cães e gatos com e sem ruptura do ligamento cruzado cranial.] A influência dos ângulos da parte proximal da tíbia sobre a ruptura do ligamento cruzado cranial (LCC) em cães é ainda controversa, e pouco é descrito sobre este tópico em gatos. 0 objetivo deste estudo foi avaliar e comparar os ângulos da tíbia proximal em cães e gatos, ambas as espécies com e sem ruptura do LCC. Foram obtidos exames radiográficos retrospectivos e prospectivos das articulações do joelho e divididos em quatro grupos: no grupo 1 foram incluídas 70 imagens radiográficas da articulação do joelho de cães sem distúrbios ortopédicos (cães saudáveis), no grupo 2 foram 70 imagens radiográficas articulação do joelho de cães com ruptura do LCC, no grupo 3 foram 50 imagens radiográficas da articulação do joelho de gatos sem distúrbios ortopédicos (gatos saudáveis), e no grupo 4 foram 25 imagens radiográficas articulação do joelho de gatos com ruptura do LCC. As imagens radiográficas da articulação do joelho foram obtidas na projeção mediolateral, mantendo-se a articulação posicionada na angulação de apoio do membro pélvico. Em relação ao ângulo do platô tibial (APT), os cães com ruptura do LCC tiveram estatisticamente maiores valores médios do APT quando comparados aos cães saudáveis. Não foi observada diferença significativa em relação ao APT entre os gatos saudáveis e os gatos com ruptura do LCC. Em relação ao ângulo do ligamento patelar mensurado pelo método do platô tibial, os valores médios observados para os cães saudáveis foram significativamente mais elevados do que os valores encontrados para os cães com ruptura do LCC. De forma semelhante, os gatos saudáveis também apresentaram valores médios mais elevados do que os gatos com ruptura do LCC. Para o ângulo do ligamento patelar mensurado pelo método da tangente comum, não foram observadas diferenças significativas entre os dois grupos de cães. No entanto, entre os dois grupos de gatos, os animais com ruptura do LCC apresentaram valores médios significativamente mais elevados do que os gatos saudáveis. Em geral, os grupos de cães demonstraram valores médios mais elevados quando comparados aos grupos de gatos. Em relação ao ângulo de inserção do ligamento patelar (AILP), os cães saudáveis apresentaram valores médios significativamente mais elevados do que os cães com ruptura do LCC. No entanto, não foi observada diferença significativa entre os dois grupos de gatos. Em conclusão, o APT e o AILP possivelmente exercem influência na etiologia da ruptura do LCC em cães, mas não influenciam nos gatos. Em gatos, os reduzidos ângulos do ligamento patelar observados pelo método da tangente comum podem influenciar favoravelmente na baixa incidência da ruptura do LCC nessa espécie.

TERMOS DE INDEXAÇÃO: Platô tibial, ligamento patelar, articulação do joelho, caninos, felinos, cirurgia.

\section{INTRODUCTION}

In cats, the cranial cruciate ligament (CCL) is thicker than the caudal cruciate ligament, while the opposite is true in dogs. This is assumed to be one reason for the low incidence of rupture of this ligament in felines compared with canines (McLaughlin 2002, Harasen 2005). Rupture of the CCL is generally associated with trauma to the pelvic limb in cats (Schnabl et al. 2009, Perry \& Fitzpatrick 2010). However, degenerative processes in the CCL and stifle joint have been described in some feline patients (Harasen 2005). Other possible reasons such as the anatomic conformation of the hind limbs have been little assessed (McLaughlin 2002, Schnabl et al. 2009).

The influence of the proximal tibial angles in the CCL rupture in dogs is still controversial (Arruda et al. 2015), and little is known regarding this topic in cats. Some studies have suggested that the slope of the tibial plateau may be an important predisposing factor for CCL rupture in dogs (Zeltzman et al. 2005, Osmond et al. 2006, Kim et al. 2008). However, there are few reports on the proximal tibial angles in normal cats and especially in cats with CCL rupture (Schnabl et al. 2009, Perry \& Fitzpatrick 2010). In one study, Schnabl et al. (2009) stated that a high tibial plateau angle (TPA) could predispose cats to CCL rupture.

The aim of this study was to evaluate and compare the proximal tibial angles between dogs and cats both with and without spontaneous CCL rupture. We hypothesized that TPA would differ between the healthy dogs and dogs with CCL rupture but would be similar in both groups of cats, and this difference in radiographic anatomy could influence the high prevalence of CCL rupture in dogs compared to cats.

\section{MATERIALS AND METHODS}

The study was approved by the Ethics Committee on Animal Use of the Institution (CEUA/UFLA 068/11). A total of 140 radiographic images of the stifle joints of dogs and 75 of cats were selected and divided into four groups. Group 1 consisted of 70 images of dogs without orthopedic disorders (healthy dogs) and group 2 had 70 images of dogs with CCL rupture, group 3 had 50 images of cats without orthopedic disorders (healthy cats) and group 4 had 25 images of cats with CCL rupture. Radiographic images of all healthy dogs and cats were obtained from a prospective study, thereby in groups 1 and 3 the selected healthy dogs and cats had average size and age similar to the groups of dogs and cats with CCL rupture. Radiographic images of dogs and cats with CCL rupture were obtained from a prospective and retrospective study, thereby in groups 2 and 4 the dogs and cats were of varied breeds and ages, and all had complete CCL rupture that was confirmed surgically.

Radiographs were obtained by standardizing the mediolateral projection of the stifle joint, positioned at a mean weight-bearing angle of $135^{\circ}$ for dogs and $120^{\circ}$ for cats and both with standard deviation accepted of $\pm 5^{\circ}$. The condyles of the femur were overlapped and the tibiotarsal joint was also included. The radiographs were obtained without tibial compression to prevent cranial displacement of the tibia in relation to the femur. The measurements were performed manually on the radiographic images.

The tibial plateau was defined by a line drawn between points at the cranial- and caudal-most articular margins of the medial tibial condyle. The TPA was established according to the standard method (Morris \& Lipowitz 2001, Schnabl et al. 2009). The angle of the patellar ligament in relation to the tibial plateau and the angle of the patellar ligament in relation to the common tangent at the tibiofemoral contact point were measured according to Dennler et al. (2006) and Schwandt et al. (2006). The methods for obtaining the TPA and patellar ligament angles are demonstrated in Figure 1.

Measurement of the patellar ligament insertion angle (PLIA) was also measured according to Arruda et al. (2015). A first straight line was drawn from the site of insertion of the patellar ligament at the tibial tuberosity to the tibiofemoral contact point (line X), and a second line was drawn from the site of insertion of the patellar ligament at the tibial tuberosity to the most cranial aspect of the 


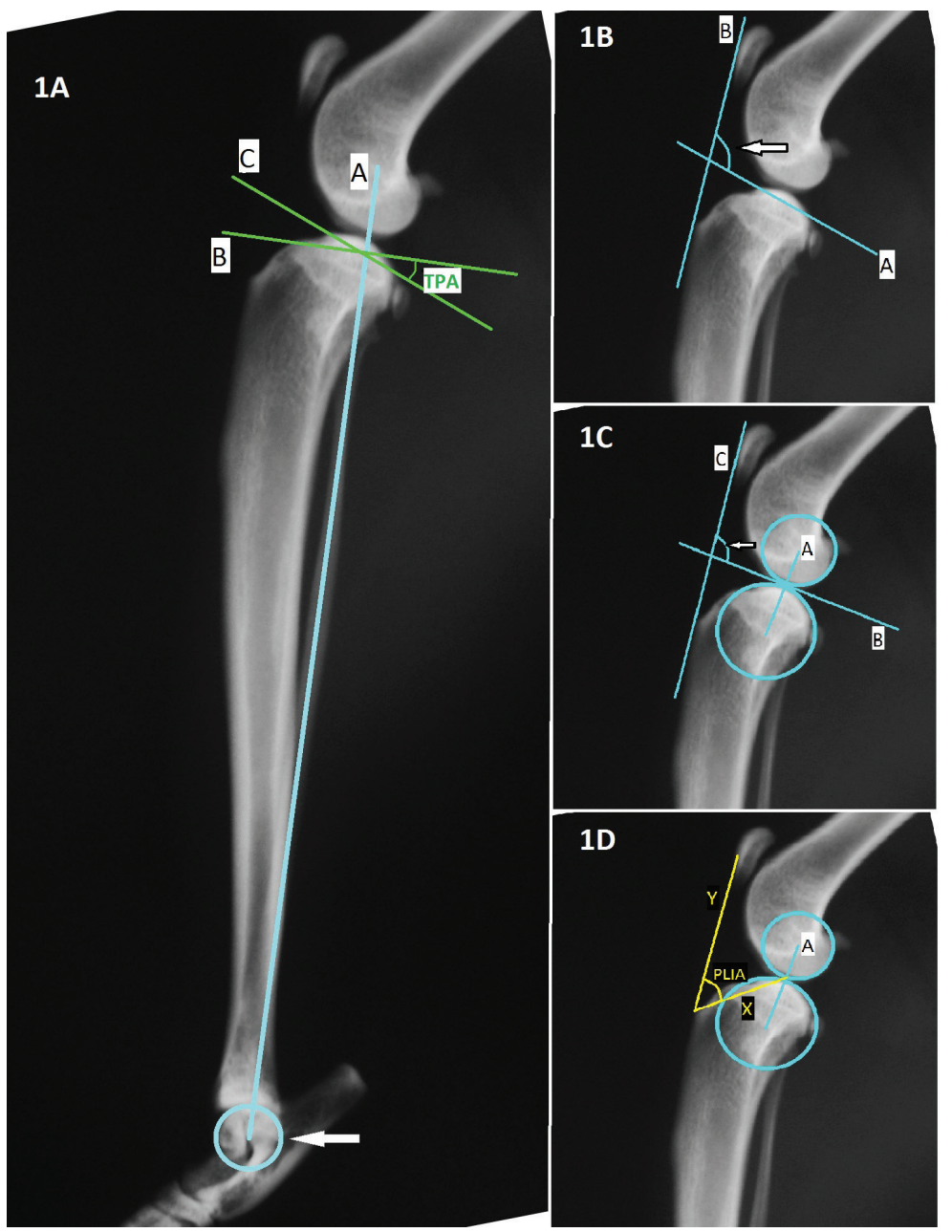

Fig.1. Radiographic images of the stifle joint in mediolateral projection of a healthy cat showing the measurements of the proximal tibial angles. (1A) Measurement of the tibial plateau angle (TPA). A circle was drawn over the articular surface of the talus (arrow). The functional axis of the tibia is defined by a line (A), drawn from the center of the intercondylar tubercles of the tibia proximally to the center of the talus distally. The tibial plateau was defined by a line (C) connecting the cranial and caudal aspect of the articular surface of the tibial condyle. The TPA was defined as the angle formed by the intersection of the tibial plateau line (C) and a line drawn perpendicular to the long axis of the tibia (B). (1B) Measurement of the angle of the patellar ligament in relation to the tibial plateau. A line was drawn on the tibial plateau (A) and another line was drawn on the cranial border of the patellar ligament (B). The angle of the patellar ligament in relation to the tibial plateau was defined as the angle formed by the intersection of these two lines (arrow). (1C) Measurement of the angle of the patellar ligament in relation to the common tangent at the tibiofemoral contact point. Two circles were drawn onto the radiographs; one circle represented the joint surface of the femoral condyles in the articulating area and the other circle outlined the area of contact on the tibial plateau. A line was drawn between the midpoints of these two circles (A), and other line was drawn perpendicular to the former within the tibiofemoral joint space (B). A line was drawn on the cranial border of the patellar ligament (C). The angle of the patellar ligament in relation to the common tangent was defined as the angle formed by the intersection of the lines B and C (arrow). (1D) Measurement of the patellar ligament insertion angle (PLIA). Similarly, a circle was drawn over the articular surface of the femoral condyles and the other circle outlined the area of contact on the tibial plateau. A line was drawn between the midpoints of these two circles (A). A line was drawn from the insertion site of the patellar ligament at the tibial tuberosity to the tibiofemoral contact point (X), and other line was drawn from the same insertion site to the most cranial aspect of the patella (Y). PLIA was defined as the angle formed by the intersection of the lines $\mathrm{X}$ and $\mathrm{Y}$.

patella (line Y). The angle formed at the meeting point of these two lines is the PLIA, as shown in Figure 1. Furthermore, the ratio between the lengths of the two lines $(X / Y)$ was calculated.

All measurements were performed in a blinded manner by an experienced observer and intraobserver analysis was also performed. All data obtained for each of the variables were tested for normality by Kolmogorov-Smirnov and analyzed by ANOVA. When the data analyzed by ANOVA were significant, data were compared among the groups and variables by Tukey's test. The variables that were not normally distributed were presented descriptively as medians and coefficients of variation. Differences were considered statistically significant when $P<0.05$.

\section{RESULTS}

The variables measured in this study had low levels of variability, with an utmost coefficient of variation of $17.41 \%$ for TPA measurements and a minimum coefficient of variation 
of 5.5\% for patellar ligament angles measured by tibial plateau method. The intraobserver variability between days was also low, with a maximum value of $3.24 \%$ for the patellar ligament angle by common tangent at the tibiofemoral contact point.

The measured values of the TPA are shown in Table 1. Between the two groups of dogs evaluated, the dogs with CCL rupture had statistically greater TPA compared with healthy dogs. Between the two groups of cats, no significant difference was observed in the TPA. In the evaluation among healthy animals of both species, dogs presented smaller mean angles than cats.

The values found for the patellar ligament angle by tibial plateau method are shown in Table 2 . The values for the group of healthy dogs were significantly higher than those for the group of CCL ruptured dogs. Similarly, healthy cats had significantly higher mean values than the group of cats with rupture of the CCL. In general, cats with CCL rupture had significantly lower mean values than the other groups.

The values measured for the angle between the patellar ligament and the common tangent at the tibiofemoral contact point are shown in Table 3. The mean values of this angle were not significantly different between the two groups of dogs. Between the two groups of cats, animals with CCL rupture had statistically higher values than healthy cats. In general, the groups of dogs showed higher mean values than the groups of cats.

The patellar ligament angles were compared between the two measurement methods used, which are the tibial plateau and the common tangent at the tibiofemoral contact point. The mean patellar ligament angles were similar between the two methods only in the group of cats with CCL rupture. In the other groups, the mean values were significantly higher when measured by the tibial plateau method compared to the common tangent.

The values obtained by calculating the ratio between the lengths of the two lines (X/Y) drawn to measure the PLIA are shown in Table 4 . The ratio X/Y was significantly different between the groups of cats, and the mean of the group of healthy cats was statistically lower than the means of the other groups. The group of cats with CCL rupture had lower mean than the group of dogs with the same injury.

The values obtained for the PLIA are shown in Table 5. Healthy dogs showed a significantly higher mean PLIA than that found in dogs with CCL rupture. There was no significant difference between the groups of cats, but the cats had significantly lower mean values than those found in dogs.

\section{DISCUSSION}

In assessing the TPA, the highest value was $33^{\circ}$ found in the groups of healthy cats and dogs with CCL rupture. The TPA in dogs can be considered excessive when exceeding $34^{\circ}$ (Duerr et al. 2008), and an extreme value of $75^{\circ}$ for the tibial plateau was found in one cat (Hoots \& Petersen 2005). Maximum TPA value of $37^{\circ}$ was observed in a CCL-ruptured cat (Schnabl et al. 2009). In the current study, none of the dogs or cats showed a TPA that was considered excessive.

By comparing the two groups of dogs, the TPA was significantly higher in dogs with CCL rupture, although all these values were near to normal considering the physiologic variation of the TPA in dogs (Watt 2000, Kim et al. 2008). In the present study, the significant difference observed between
Table 1. Values obtained by the measurement of the tibial plateau angle (TPA) in healthy dogs (group 1), dogs with CCL rupture (group 2), healthy cats (group 3) and cats with CCL rupture (group 4)

\begin{tabular}{cccccc}
\hline Group & $\begin{array}{c}\text { Mean } \pm \\
\text { Standard } \\
\text { deviation }\left({ }^{\circ}\right)\end{array}$ & $\begin{array}{c}\text { Minimum } \\
\text { value }\left({ }^{\circ}\right)\end{array}$ & $\begin{array}{c}\text { Maximum } \\
\text { value }\left({ }^{\circ}\right)\end{array}$ & $\begin{array}{c}P \\
\text { value }\end{array}$ & CV (\%) \\
\hline 1 & $20.58 \pm 3.62^{\mathrm{b}}$ & 12 & 30 & $<0.01$ & 17.41 \\
2 & $24.27 \pm 4.18^{\text {a }}$ & 14 & 33 & & \\
3 & $24.84 \pm 4.05^{\text {a }}$ & 16 & 33 & & \\
4 & $22.72 \pm 4.51^{\text {ab }}$ & 13 & 30 & &
\end{tabular}

$\overline{a, b}$ The means followed by different letters in the column differed statistically.

Table 2. Values of the patellar ligament angle obtained by tibial plateau method in healthy dogs (group 1), dogs with CCL rupture (group 2), healthy cats (group 3) and cats with CCL rupture (group 4)

\begin{tabular}{cccccc}
\hline Group & $\begin{array}{c}\text { Mean } \pm \\
\text { Standard } \\
\text { deviation }\left({ }^{\circ}\right)\end{array}$ & $\begin{array}{c}\text { Minimum } \\
\text { value }\left(^{\circ}\right)\end{array}$ & $\begin{array}{c}\text { Maximum } \\
\text { value }\left(^{\circ}\right)\end{array}$ & $\begin{array}{c}P \\
\text { value }\end{array}$ & CV (\%) \\
\hline 1 & $104.95 \pm 5.63^{\mathrm{a}}$ & 86 & 120 & $<0.01$ & 5.50 \\
2 & $100.24 \pm 5.39^{\mathrm{b}}$ & 89 & 115 & & \\
3 & $98.76 \pm 4.97^{\mathrm{b}}$ & 90 & 112 & & \\
4 & $92.36 \pm 6.63^{\mathrm{c}}$ & 78 & 103 & &
\end{tabular}

a, b, c The means followed by different letters in the column differed. statistically.

Table 3. Values of the patellar ligament angle obtained by common tangent at the tibiofemoral contact point method in healthy dogs (group 1), dogs with CCL rupture (group 2), healthy cats (group 3) and cats with CCL rupture (group 4)

\begin{tabular}{cccccc}
\hline Group & $\begin{array}{c}\text { Mean } \pm \\
\text { Standard } \\
\left.\text { deviation }^{\circ}{ }^{\circ}\right)\end{array}$ & $\begin{array}{c}\text { Minimum } \\
\text { value }\left(^{\circ}\right)\end{array}$ & $\begin{array}{c}\text { Maximum } \\
\text { value }\left(^{\circ}\right)\end{array}$ & $\begin{array}{c}P \\
\text { value }\end{array}$ & CV (\%) \\
\hline 1 & $98.00 \pm 6.57^{\text {a }}$ & 81 & 117 & $<0.01$ & 10.42 \\
2 & $97.87 \pm 3.74^{\mathrm{a}}$ & 91 & 110 & & \\
3 & $89.60 \pm 4.53^{\mathrm{c}}$ & 67 & 97 & & \\
4 & $93.16 \pm 5.96^{\mathrm{b}}$ & 83 & 106 & &
\end{tabular}

a, b, c The means followed by different letters in the column differed statistically.

Table 4. Values obtained by calculating the ratio between the lengths of the two lines $(X / Y)$ drawn to measure the patellar ligament insertion angle (PLIA) in healthy dogs (group 1), dogs with CCL rupture (group 2), healthy cats (group 3) and cats with CCL rupture (group 4)

\begin{tabular}{cccccc}
\hline Group & $\begin{array}{c}\text { Mean } \pm \\
\text { Standard } \\
\text { deviation }\left({ }^{\circ}\right)\end{array}$ & $\begin{array}{c}\text { Minimum } \\
\text { value }\left({ }^{\circ}\right)\end{array}$ & $\begin{array}{c}\text { Maximum } \\
\text { value }\left({ }^{\circ}\right)\end{array}$ & $\begin{array}{c}P \\
\text { value }\end{array}$ & CV (\%) \\
\hline 1 & $0.69 \pm 0.05^{\mathrm{ab}}$ & 0.56 & 0.78 & $<0.01$ & 8.16 \\
2 & $0.70 \pm 0.06^{\mathrm{a}}$ & 0.55 & 0.82 & & \\
3 & $0.62 \pm 0.05^{\mathrm{c}}$ & 0.53 & 0.73 & \\
4 & $0.66 \pm 0.06^{\mathrm{b}}$ & 0.52 & 0.75 & \\
\hline a, b, c The means followed by different letters in the column differed \\
statistically.
\end{tabular}


Table 5. Values obtained by the measurement of the patellar ligament insertion angle (PLIA) in healthy dogs (group 1), dogs with CCL rupture (group 2), healthy cats (group 3) and cats with CCL rupture (group 4)

\begin{tabular}{cccccc}
\hline Group & $\begin{array}{c}\text { Mean } \pm \\
\text { Standard } \\
\text { deviation }\left({ }^{\circ}\right)\end{array}$ & $\begin{array}{c}\text { Minimum } \\
\text { value }\left(^{\circ}\right)\end{array}$ & $\begin{array}{c}\text { Maximum } \\
\text { value }\left({ }^{\circ}\right)\end{array}$ & $\begin{array}{c}P \\
\text { value }\end{array}$ & CV (\%) \\
\hline 1 & $53.82 \pm 4.12^{\mathrm{a}}$ & 46 & 64 & $<0.01$ & 8.84 \\
2 & $48.99 \pm 4.64^{\mathrm{b}}$ & 38 & 59 & & \\
3 & $41.67 \pm 3.67^{\mathrm{c}}$ & 34 & 51 & & \\
4 & $43.68 \pm 4.41^{\mathrm{c}}$ & 36 & 50 & &
\end{tabular}

$\overline{a, b, c}$ The means followed by different letters in the column differed statistically.

the groups of dogs highlights the possible influence of the TPA in the pathogenesis of CCL rupture in dogs (Morris \& Lipowitz 2001, Haynes et al. 2015).

There was no significant difference between the two groups of cats evaluated in relation to the TPA. Conversely in another study, the TPA in normal cats were significantly lower than those in cats with CCL rupture; and the authors cited a probable influence of the TPA in ligament rupture in cats (Schnabl et al. 2009). However, in the current study, the similarity of values between the groups of cats indicates that the tibial plateau slope is unlikely to influence CCL rupture in cats, highlighting the importance of the traumatic etiology of ligament rupture in this species.

A normal patellar ligament angle in relation to the tibial plateau is approximately $105^{\circ}$ when the stifle joint is angled at $135^{\circ}$ in dogs (Kim et al. 2008). Similar values were found in the group of healthy dogs in the current study. When it was compared between the two groups of dogs and between the two groups of cats, the animals with CCL rupture had a lower mean patellar ligament angle than the healthy animals. These results suggest that there is a change in the patellar ligament position after the complete rupture of the CCL. Similarly in a radiographic study, the patellar ligament angle of dogs with ruptured CCL was significantly lower than that of normal dogs (Lee \& Jeong 2014).

In the tibial tuberosity advancement theory for the treatment of CCL rupture, it is necessary to reduce the patellar ligament angle to approximately $90^{\circ}$ to neutralize the cranial tibial thrust, with the stifle joint kept in a supporting position (Kim et al. 2008, Cadmus et al. 2014). In the current study, the patellar ligament angles from the two groups of cats approached the value that is considered optimal to neutralize these forces, especially when measured by the method of the common tangent at the tibiofemoral contact point. Thus, it can be stated that in cats, the angle of the patellar ligament obtained by common tangent method can favor the reduction of the cranial tibial thrust and possibly the annulment of harmful forces on the CCL.

In a previous study with dogs no statistically significant difference was found between the two methods of measurement of the patellar ligament angle. The authors cited that both methods can be used but indicated a preference for the common tangent at the tibiofemoral contact point method (Schwandt et al. 2006). In another study, the patellar ligament angle values obtained by the common tangent method were lower than the anatomical patellar ligament measurements and conversely, those obtained by conventional method were systematically higher (Bismuth et al. 2014). In the current study, the mean of these angles was significantly higher when obtained using the tibial plateau method compared with the common tangent method. It seems there is a tendency to overestimate the patellar ligament angles when using the conventional method of the tibial plateau (Drygas et al. 2010). However, in the present study, patellar ligament angle measures made by the tibial plateau method demonstrated a lower coefficient of variation than the common tangent method.

In the current study, with the intention to develop a more accurate method to evaluate the lever arm of the extensor mechanism, the PLIA was measured and ratio of the lengths of the lines $(\mathrm{X} / \mathrm{Y})$ was calculated to allow for the comparison of values between animals of different sizes (Arruda et al. 2015). Theoretically, a longer patellar tendon lever arm will lower the required strength of the quadriceps to move the tibia and promote extension of the stifle joint (Boudrieau 2009 , Guerrero et al. 2011). In this study, the group of healthy cats demonstrated a lower mean X/Y ratio compared with the means of the other groups, which does not confirm the theory that a longer lever arm decreases stress and has a protective effect on the ligaments of the joint.

Regarding the PLIA, a smaller angle is believed to be associated with a greater force required to extend the stifle joint (Arruda et al. 2015), and this increased force could overload the patellar ligament and CCL. Given that, in the current study dogs with CCL rupture had a lower mean PLIA than that found in healthy dogs, which suggests the possible interference of a reduced PLIA in CCL rupture in dogs. However, no difference in the PLIA was observed between the groups of cats, which reduces the possible role of this angle in the etiology of CCL rupture in cats.

\section{CONCLUSIONS}

The TPA and the PLIA possibly influence the etiology of CCL rupture in dogs but not in cats.

The low patellar ligament angle measured by common tangent method may favorably influence the reduced incidence of CCL rupture in cats.

Conflict of interest statement.- The authors declare that there is no conflict of interest.

Acknowledgements.- The authors acknowledge the financial support provided by FAPEMIG and CAPES.

\section{REFERENCES}

Arruda A.F.D.P., Muzzi L.A.L., Muzzi R.A.L., Lacreta Júnior A.C.C., Oberlender G. \& Silva W.G. 2015. Comparison of the proximal tibial angles between Labrador Retrievers and other dog breeds with and without cranial cruciate ligament rupture. Arq. Bras. Med. Vet. Zootec. 67(5):1254-1262. http:// dx.doi.org/10.1590/1678-4162-8070.

Bismuth C., Ferrand F.X., Millet M., Labrunie A., Marin B., Pillard P., Deroy C., Fau D., Carozzo C., Cachon T. \& Viguier E. 2014. Comparison of radiographic measurements of the patellar tendon-tibial plateau angle with anatomical measurements in dogs. Vet. Comp. Orthop. Traumatol. 27(3):222-229. http://dx.doi.org/10.3415/VCOT-13-12-0145. PMid:24763422.

Boudrieau R.J. 2009. Tibial plateau leveling osteotomy or tibial tuberosity advancement? Vet. Surg. 38(1):1-22. http://dx.doi.org/10.1111/j.1532950X.2008.00439.x. PMid:19152613. 
Cadmus J., Palmer R.H. \& Duncan C. 2014. The effect of preoperative planning method on recommended tibial tuberosity advancement cage size. Vet. Surg. 43(8):995-1000. http://dx.doi.org/10.1111/j.1532-950X.2014.12126.x. PMid:24410754.

Dennler R., Kipfer N.M., Tepic S., Hassig M. \& Montavon P.M. 2006. Inclination of the patellar ligament in relation to flexion angle in stifle joints of dogs without degenerative joint disease. Am. J. Vet. Res. 67(11):1849-1854. http://dx.doi.org/10.2460/ajvr.67.11.1849. PMid:17078745.

Drygas K.A., Pozzi A., Goring R.L., Horodyski M. \& Lewis D.D. 2010. Effect of tibial plateau leveling osteotomy on patellar tendon angle: A radiographic cadaveric study. Vet. Surg. 39(4):418-424. http://dx.doi.org/10.1111/j.1532950X.2010.00665.x. PMid:20345525.

Duerr F.M., Duncan C.G., Savicky R.S., Park R.D., Egger E.L. \& Palmer R.H. 2008. Comparison of surgical treatment options for cranial cruciate ligament disease in large-breed dogs with excessive tibial plateau angle. Vet. Surg. 37(1):49-62. http://dx.doi.org/10.1111/j.1532-950X.2007.00348.x. PMid:18199057.

Guerrero T.G., Pozzi A., Dunbar N., Kipfer N., Haessig M., Beth Horodyski M. \& Montavon P.M. 2011. Effect of tibial tuberosity advancement on the contact mechanics and the alignment of the patellofemoral and femorotibial joints. Vet. Surg. 40(7):839-848. PMid:21848944.

Harasen G.L.G. 2005. Feline cranial cruciate rupture: 17 cases and a review of the literature. Vet. Comp. Orthop. Traumatol. 18(4):254-257. http:// dx.doi.org/10.1055/s-0038-1632963. PMid:16594395.

Haynes K.H., Biskup J., Freeman A. \& Conzemius M.G. 2015. Effect of tibial plateau angle on cranial cruciate ligament strain: an ex vivo study in the dog. Vet. Surg. 44(1):46-49. PMid:24902869.

Hoots E.A. \& Petersen S.W. 2005. Tibial plateau leveling osteotomy and cranial closing wedge ostectomy in a cat with cranial cruciate ligament rupture. J. Am. Anim. Hosp. Assoc. 41(6):395-399. http://dx.doi.org/10.5326/0410395. PMid:16267064.

Kim S.E., Pozzi A., Kowaleski M.P. \& Lewis D.D. 2008. Tibial osteotomies for cranial cruciate ligament insufficiency in dogs. Vet. Surg. 37(2):111-125. http://dx.doi.org/10.1111/j.1532-950X.2007.00361.x. PMid:18251804.
Lee J.H. \& Jeong S.W. 2014. Feasibility of utilizing the patellar ligament angle for assessing cranial cruciate ligament rupture in dogs. J. Vet. Sci. 15(4):563568. http://dx.doi.org/10.4142/jvs.2014.15.4.563. PMid:24962409.

McLaughlin R.M. 2002. Surgical diseases of the feline stifle joint. Vet. Clin. N. Am., Small Anim. Pract. 32(4):963-982. http://dx.doi.org/10.1016/ S0195-5616(02)00021-9. PMid:12148321.

Morris E. \& Lipowitz A.J. 2001. Comparison of tibial plateau angles in dogs with and without cranial cruciate ligament injuries. J. Am. Vet. Med. Assoc. 218(3):363-366. http://dx.doi.org/10.2460/javma.2001.218.363. PMid:11201561.

Osmond C.S., Marcellin-Little D.J., Harrysson O.L.A. \& Kidd L.B. 2006. Morphometric assessment of the proximal portion of the tibia in dogs with and without cranial cruciate ligament rupture. Vet. Radiol. Ultrasound 47(2):136-141. http://dx.doi.org/10.1111/j.1740-8261.2006.00119.x. PMid:16553144.

Perry K. \& Fitzpatrick N. 2010. Tibial tuberosity advancement in two cats with cranial cruciate ligament deficiency. Vet. Comp. Orthop. Traumatol. 23(3):196-202. PMid:20422116.

Schnabl E., Reese S., Lorinson K. \& Lorinson D. 2009. Measurement of the tibial plateau angle in cats with and without cranial cruciate ligament rupture. Vet. Comp. Orthop. Traumatol. 22(2):83-86. http://dx.doi.org/10.3415/ VCOT-07-12-0112. PMid:19290387.

Schwandt C.S., Bohorquez-Vanelli A., Tepic S., Hassig M., Dennler R., Vezzoni A. \& Montavon P.M. 2006. Angle between the patellar ligament and tibial plateau in dogs with partial rupture of the cranial cruciate ligament. Am. J. Vet. Res. 67(11):1855-1860. http://dx.doi.org/10.2460/ajvr.67.11.1855. PMid:17078746.

Watt P. 2000. Tibial plateau leveling. Aust. Vet. J. 78(6):385-386. http://dx.doi. org/10.1111/j.1751-0813.2000.tb11821.x. PMid:10920775.

Zeltzman P.A., Paré B., Johnson G.M., Zeltzman V., Robbins M.A. \& Gendreau C.L. 2005. Relationship between age and tibial plateau angle in dogs with cranial cruciate rupture. J. Am. Anim. Hosp. Assoc. 41(2):117-120. http:// dx.doi.org/10.5326/0410117. PMid:15767655. 